\title{
TWO PHASE DEVELOPMENT OF THE UPPER CERKNIŠČICA BASIN
}

\section{DVOFAZNI RAZVOJ ZGORNJEGA DELA POREČJA CERKNIŠČICE}

\author{
SIMONA ŠUŠTERŠIČ $\check{1}^{1}$
}

${ }^{1}$ Laze 22, 1370 LOGATEC, SLOVENIJA, e-mail: simona_sustersic@hotmail.com

Prejeto / received: 15.10 .2002 


\section{Simona Šušteršič: Dvofazni razvoj zgornjega dela porečja Cerkniščice}

Porečje Cerkniščice obsega $46,8 \mathrm{~km}^{2}$ in je reliefno precej pestro. Reliefna pestrost ni posledica velike kamninske pestrosti, saj večino porečja gradi zgornjetriasni dolomit. Glavno vlogo pri tem ima različna pretrtost dolomita. Več raziskovalcev meni, da se rečne terase v porečju Cerkniščice nahajajo v večih nivojih. Z rekonstrukcijo vzdolžnih rečnih profilov Cerkniščice oz. njene predhodnice in njenih glavnih pritokov pa se je pokazalo, da v porečju Cerkniščice pravih večstopenjskih teras ni. Vzdolž toka se namreč pojavljata le dva značilna nivoja: starejši in mlajši. Starejši nivo je 10-40 m višje od mlajšega in predstavlja uravnavo, ki jo je izdelala predhodnica Cerkniščice, ko je le-ta ponikala pri Begunjah in vodo podzemsko odvajala še v smeri proti Logatcu. Mlajši nivo predstavlja dno današnje Cerkniščice in se je začel oblikovati ob koncu Würma v trenutku, ko je voda iz porečja preusmerila tok in začela odtekati proti Cerkniškemu polju. Takrat je bilo ravnotežje zaradi spremembe razmer (nova erozijska baza, krajša odtočna razdalja in s tem večji strmec) v porečju porušeno in prisiljeno se je bilo prilagajati novim razmeram. Da bi ustvarila novo ravnotežje, se je Cerkniščica začela vrezovati v starejši nivo.

Ključne besede: geomorfologija, krasoslovje, pretočitev, brezstrope jame, Cerkniščica, Slovenija.

\section{Abstract}

UDC: $556.52(497.4)$

\section{Simona Šušteršič: Two phase development of the upper Cerkniščica basin}

The Cerkniščica catchement area covers about $46.8 \mathrm{~km}^{2}$, and most of the area is built of upper Triassic dolomite. So, the differences in the surface roughness are mostly not due to variable lithology, but to diffent degrees of tectonically injurred rock. Reconstruction of longitudinal profiles of the main river and of its tributaries revealed that there do not exist multiple terraces, as believed before. Rather, the river formed only two distinct levels. The older one is about 10-40 m higher, a wide, well equilibrated valley. It was formed by the predecessor of the present Cerkniščica, at the time when the river sank in the area of Begunje and continued its way towards Logatec underground. The younger level is controlled by the inrush of the river into Cerkniško polje. Sudden lowering of the erosion base, by the end of Würm, provoked rapid incision into the earlier surface, and the formation of canyon-like entrenchment.

Key words: geomorphology, karst, stream piracy, unroofed caves, Cerkniščica, Slovenia. 


\section{INTRODUCTION}

The Cerkniščica is the only surface tributary entering Cerkniško polje. It is $18.5 \mathrm{~km}$ long and its average annual discharge is $1.23 \mathrm{~m}^{3} / \mathrm{s}$ (Žibrik \& Pičinin, 1976).

The area of the Cerkniščica catchment is $46.8 \mathrm{~km}^{2}$ and it represents an oasis of fluvial relief in the middle of the karst. Overall it is bowl-shaped, and its floor is relatively flat. The Upper Triassic (Norian-Rhaetian) dolomite parent rock is strongly crushed and the relief is quite uneven. Fluviodenudational and fluviodepositional landforms dominate, whereas the fluviokarst and karst are relatively subdued.

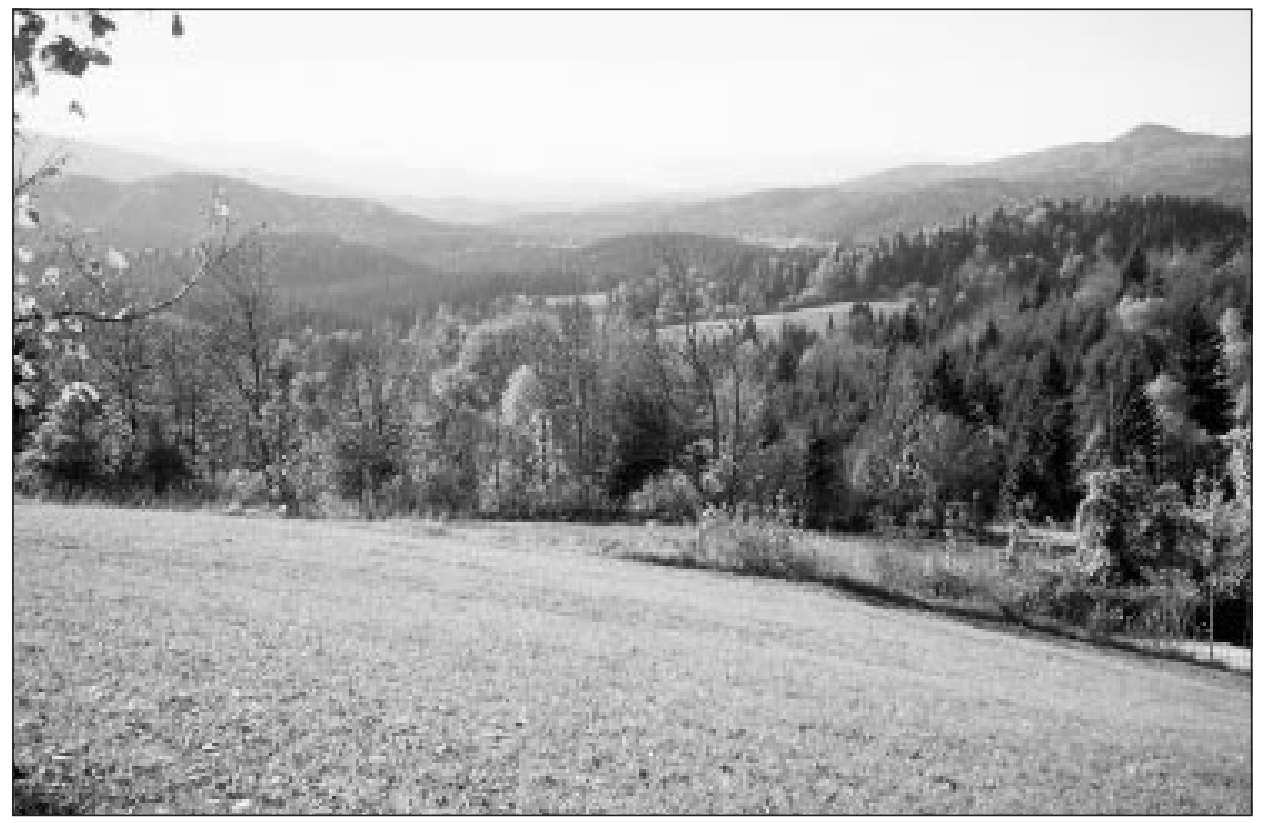

Fig. 1: Bowl-shaped catchment area with relatively flat floor formed by the Begunjščica (Photo: S. Šušteršič).

Sl. 1: Porečje je skledaste oblike s precej uravnanim dnom, ki ga je izdelala Begunjščica (Foto: S. Šušteršič).

Among various factors the development of the Cerkniščica catchment was controlled mainly by the nature of the outflow. Initially flow was on the surface as far as Begunje, where the river sank and then continued underground towards Logatec. This has been confirmed by observation of characteristic sediments in now unroofed caves (Šušteršič, 1998). Then, about 50 thousand years ago, the river changed direction and turned towards Cerkniško polje.

Early researchers (Melik, 1959; Gospodarič \& Habič, 1979) believed that fluvial terraces within the catchment occur at several discrete levels. Thus, this research set out to investigate whether the terraces are the result of a number of erosional and depositional phases, or whether they are simply the result of the events already mentioned. 


\section{METHODS AND APPROACHES}

\section{Mapping of terraces}

Along the Cerkniščica, about 10 to $40 \mathrm{~m}$ above the river bed, flat areas that resemble terraces appear at several places. In the upper part of the catchment they lie at elevations between 690 and $630 \mathrm{~m}$, whereas in the lower part (near Begunje) they are between 630 and $610 \mathrm{~m}$.

The characteristic load of today's Cerkniščica is dominated by dolomite gravel, but it also includes relatively small proportions of oolitic bauxite and black chert. Outcrops of these two rocks are present in the higher parts of the catchment. After finding small pieces of such material on some of the terraces I hypothesised that it was brought there and deposited by the water flow of the earlier Cerkniščica. Many of the dolomite pebbles, which were initially dominant, have since been weathered away.

After mapping the terraces my impression is that only two tiers exist:

- an older one, adjusted to the level of the former ponors at Begunje, and

- a younger one related to later incision of the Cerkniščica into the older terrace, and controlled by the level of Cerkniško polje.

Traditionally, the river that was active during the early phase is known as the Begunjščica.

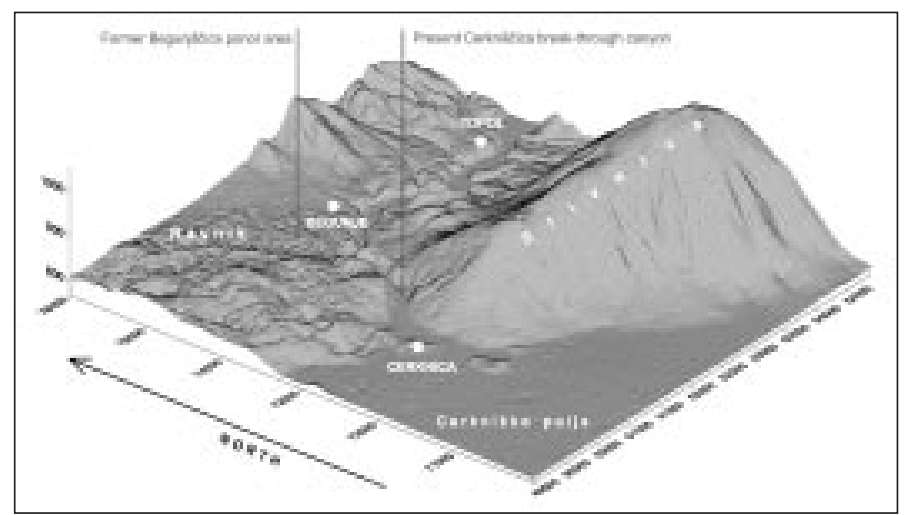

Fig. 2: Digital Elevation Model of the former Begunjščica ponor area and the present Cerkniščica break-through canyon.

Sl. 2: Digitalni model reliefa nekdanjega ponornega območja Begunjščice in prebojne doline Cerkniščice.

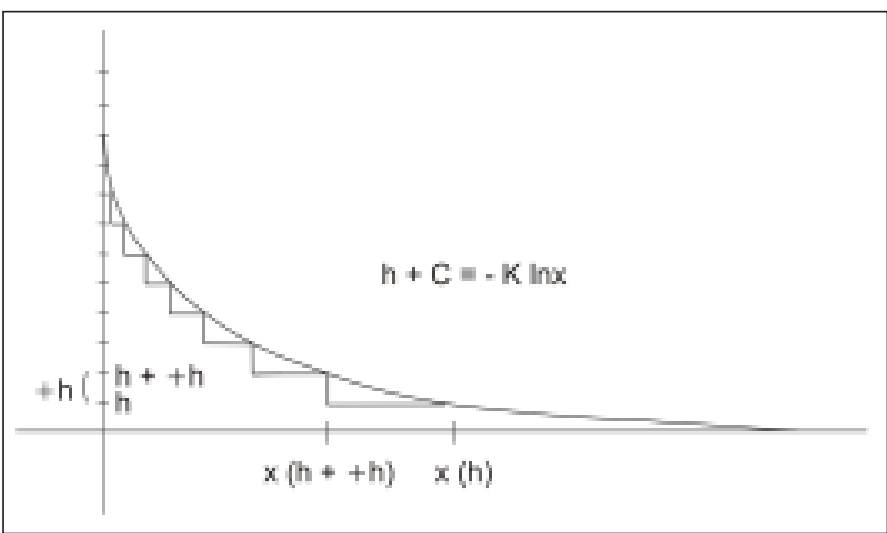

Fig. 3: Equilibrium longitudinal profile.

Sl. 3: Uravnoteženi vzdolžni profil. 


\section{Reconstruction of the situation before the river's redirection}

Before the Begunjščica was redirected towards Cerkniško polje the flow was on the surface as far as Begunje, where the river sank and continued underground towards Logatec. This is confirmed by the preservation of remnants of dolomite gravel, oolitic bauxite and black chert, which are spread across about half a square kilometre south of Begunje. These sediments are preserved only below an elevation of $610 \mathrm{~m}$. The neighbouring area was searched in great detail, but no occurrences were found at higher levels. However, extensive remnants of apparently older unroofed caves were recognized, containing flowstone and clastic sediments (Šušteršič, 2002).

\section{Mathematical modelling of terraces}

Mathematical models of equilibrium profiles of the Cerkniščica and its main tributaries were employed to test the working hypothesis that only two tiers exist and that the existence of different levels is a fallacy, as so close to the source terraces should not be horizontal, nor even nearly horizontal.

The model proposed by Connelly (1972) was used.

The shape of longitudinal profiles depends on several factors, but the final equation for calculating the level of equilibration is given by Bernoulli's equation:

$$
E=\gamma V h+\left(V \rho v^{2} / 2\right) \quad(\text { equation No. } 1)
$$

- $\gamma W h=$ potential energy:

- $\gamma=$ specific weight of water;

- $V=$ volume;

- $h=$ height;

- $\left(V \rho v^{2} / 2\right)=$ kinetic energy:

- $v=$ velocity of the water;

- $\rho=$ density of water.

The equation supposes that rivers tend to equilibrate their longitudinal profiles with the minimum loss of energy. Such an idealised profile is called an equilibrium longitudinal profile, and the final equation is then:

$$
C+h=-K \ln x \quad \text { (equation No. 2) }
$$

- $h=$ topographic height;

- $x=$ horizontal distance;

- $\quad C$ and $K=$ constants.

Using equation No.2, the equilibrium profiles of the Cerkniščica and its main tributaries were calculated, and these were compared with the actual profiles. 


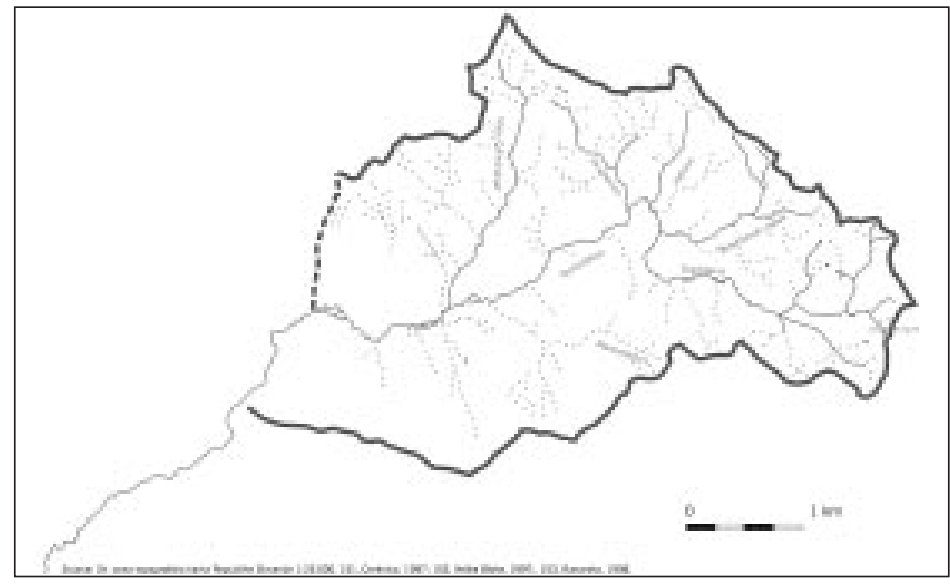

Fig. 4: Drainage network of the Cerkniščica catchment area. Sl. 4: Hidrografska mreža porečja Cerkniščice.

The present long profile of the Cerkniščica is almost in equilibrium, but nowhere completely equilibrated. As the whole of the river flows across Upper Triassic dolomite, the irregularities appear to be random or related to local conditions.

The long profile was reconstructed on the basis of unequivocal elevations of the Begunjščica (early Cerkniščica). It turned out to be almost equilibrated to the former ponor area at Begunje (Šušteršič, 2002).

Elevations on the calculated longitudinal profile matched well with elevations on the terraces along the Cerkniščica valley. This suggests that the terraces belong to the same tier (Šušteršič, S., 2002).

However, the present Cerkniščica valley floor, formed after the river's redirection, is incised into the bottom of the Begunjščica valley.

As it is relatively wide and well equilibrated the Begunjščica valley indicates that, compared to the present Cerkniščica, this phase lasted much longer (Šušteršič, 2002).

Some of the Cerkniščica's main tributaries - the Jazbine, Mahneščica and Mala Cerkniščica are also not equilibrated. The upper parts of their profiles were equilibrated to Begunjščica, and their former long profiles were reconstructed on this basis. It transpired that, at the approximate locations of their confluences with the Begunjščica, the calculated elevations were nearly the same as the actual elevation of the Begunjščica. Correspondence was exact in the case of the Jazbine and the Mahneščica, but the inflow to the Mala Cerkniščica was about 70m higher. Such a difference can probably be explained as being a consequence of neotectonic activity.

\section{RESULTS}

The main results obtained by field mapping and mathematical modelling are:

1. There were only two phases of incision in the upper Cerkniščica basin;

2. The Begunjščica (early Cerkniščica) was nearly equilibrated to the ponor area at Begunje;

3. There are only two characteristic levels: the older one, adapted to Begunjščica, and the younger one, related to Cerkniščica;

4. Redirection of the Cerkniščica to Cerkniško polje was a catastrophic event;

5. The elevation of the fossil ponor area revealed near Begunje is several dozen metres lower than the ridge between the Begunje ponor area and Cerkniško polje. 


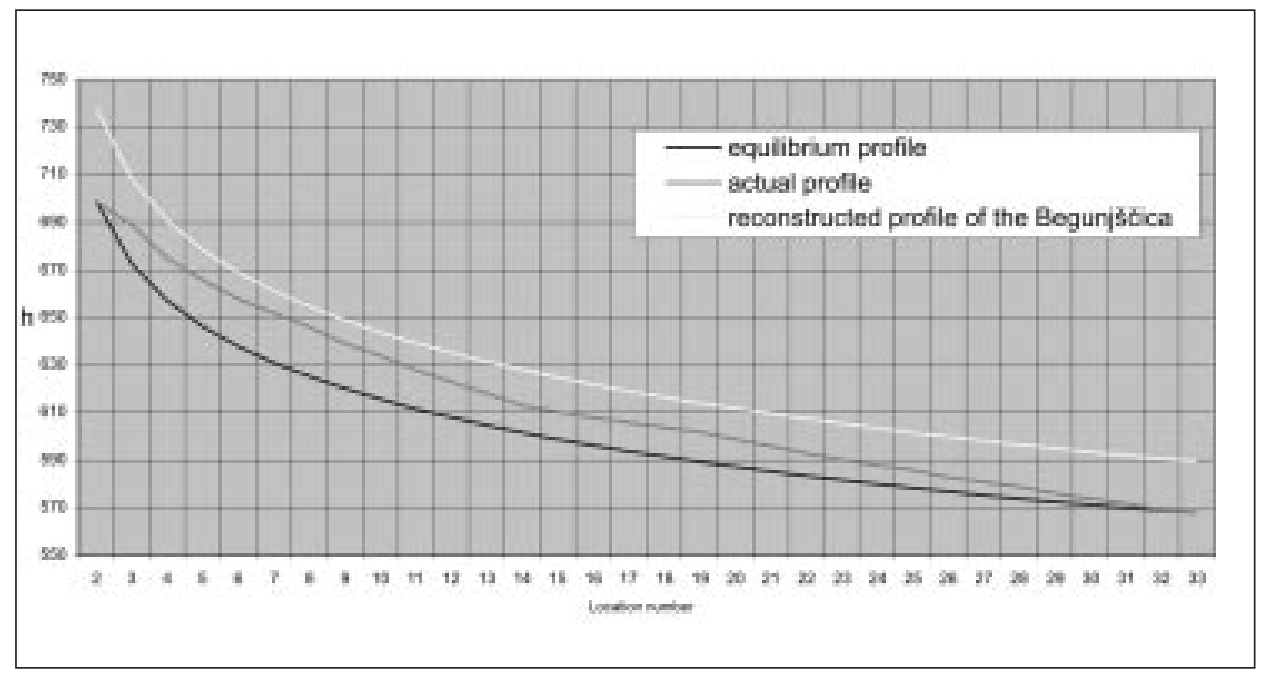

Graph 1: Comparison between actual and equilibrium profile of the Cerkniščica. Reconstruction of former Begunjščica.

Graf 1: Primerjava dejanskega in uravnoteženega vzdolžnega profila Cerkniščice ter idealizirana rekonstrukcija nekdanjega profila Begunjščice.

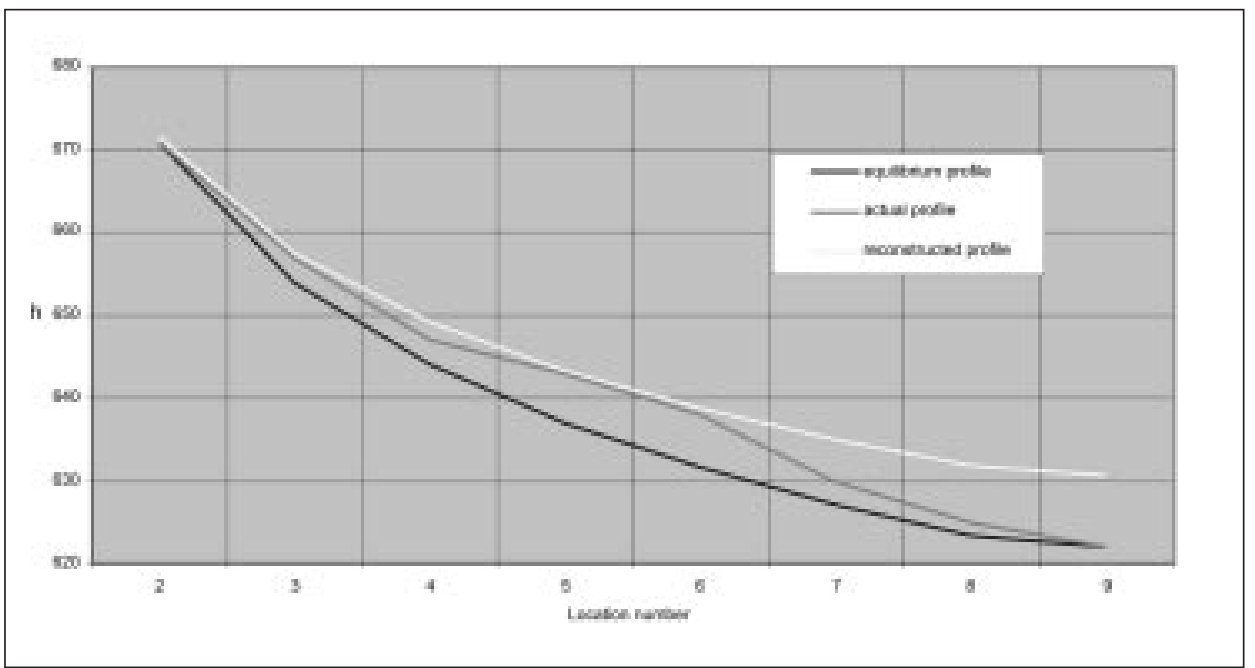

Graph 2: Comparison between actual and equilibrium profile of the Jazbine stream. Reconstruction of former profile.

Graf 2: Primerjava dejanskega in uravnoteženega vzdolžnega profila potoka Jazbine ter idealizirana rekonstrukcija nekdanjega profila. 


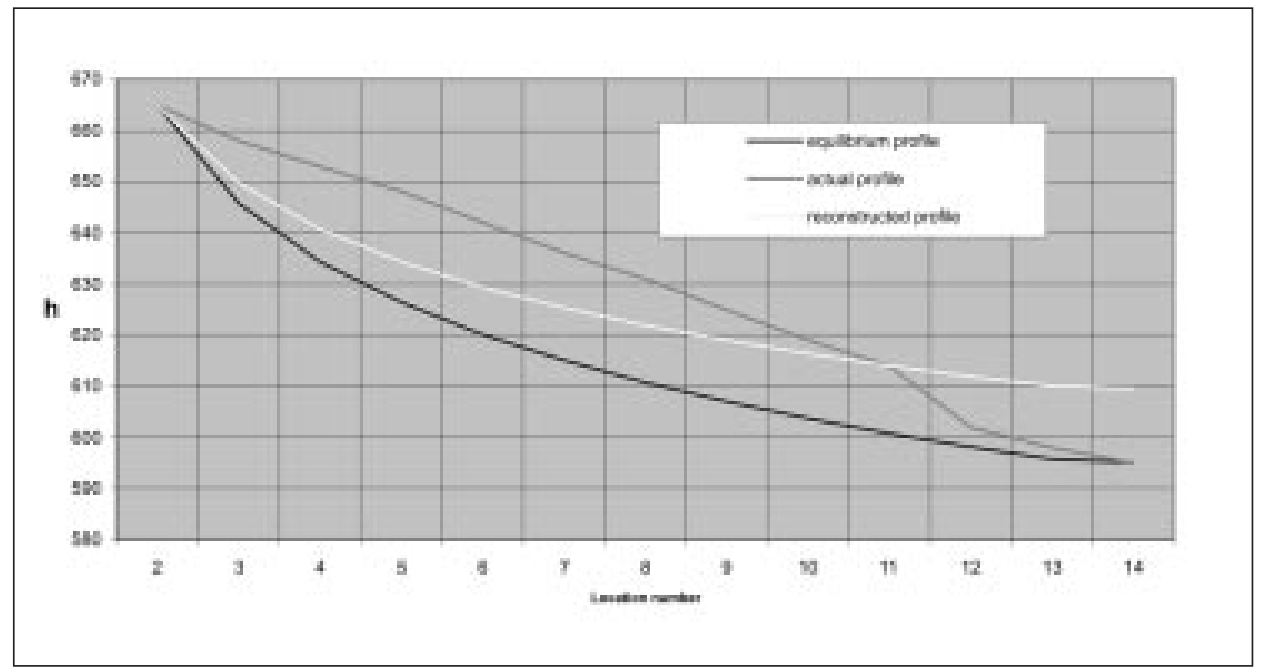

Graph 3: Comparison between actual and equilibrium profile of the Mahneščica stream. Reconstruction of former profile.

Graf 3: Primerjava dejanskega in uravnoteženega vzdolžnega profila potoka Mahneščica ter idealizirana rekonstrukcija nekdanjega profila.

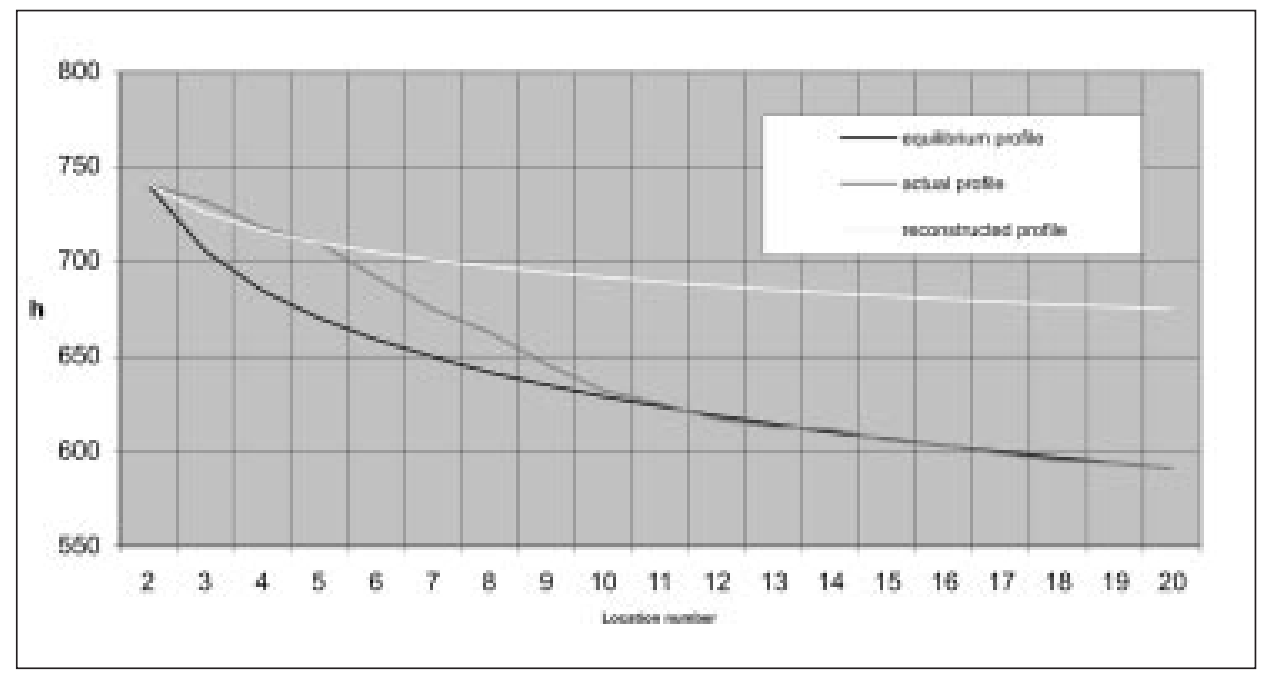

Graph 4: Comparison between actual and equilibrium profile of the Mala Cerkniščica stream. Reconstruction of former profile.

Graf 4: Primerjava dejanskega in uravnoteženega vzdolžnega profila Male Cerkniščice ter idealizirana rekonstrukcija nekdanjega profila. 


\section{DISCUSSION AND CONCLUSIONS}

Two related questions remain: how and why did the redirection occur, if there are no characteristic sediments on the dividing ridge between the former ponor area and Cerkniško polje?

The answer to these questions is offered by the existence of various large unroofed caves that have been mapped in that area. These belong to a very old cave system, formed more than 2 million years ago, before strike slip movement occurred along the Idria Fault. The system's existence was predicted statistically by F. Šušteršič (1996).

So it is very likely that at some point the Begunjščica reactivated an already existing cave system, washed it clear of sediment, and eventually re-used pre-existing channels. However, a steep gradient and relatively thin ceilings did not allow the system to remain stable, and the cave soon developed into the present canyon (Šušteršič, 2002).

Why the re-direction did not take place earlier, must be the subject of further investigation.

\section{REFERENCES}

Connelly, D.S., 1972: Geomorphology and information theory. In: Chorley, R.J.: Spatial Analysis in Geomorphology. London, Methuen, 393 p.

Gospodarič, R., Habič, P., 1979: Kraški pojavi Cerkniškega jezera. Acta carsologica, 8, p. 7-162.

Melik, A., 1959: Posavska Slovenija. Slovenija - geografski opis. 3. zv., Ljubljana, Slovenska matica, $586 \mathrm{p}$.

Šušteršič, F., 1996: Poljes and caves of Notranjska. Acta carsologica, 25, p. 252-289.

Šušteršič, F., 1998: Interaction between cave systems and the lowering karst surface; case study: Laški Ravnik. Acta carsologica, 27, 2, p. 115-138.

Šušteršič, S., 2002: Geografske značilnosti in razvoj porečja Cerkniščice: diplomsko delo. Ljubljana, Filozofska fakulteta, Oddelek za geografijo, 96 p.

Žibrik, K., Pičinin, A., 1976: K hidrologiji kraškega porečja Ljubljanice. In: 3. mednarodni simpozij o sledenju podzemskih voda, Poročila 1. Ljubljana, Jugoslovanski komite za mednarodno hidrološko dekado, p. 3-7.

\section{DVOFAZNI RAZVOJ ZGORNJEGA DELA POREČJA CERKNIŠČICE}

\section{Povzetek}

Razvoj porečja Cerkniščice je bil v največji meri odvisen od načina odtoka vode iz njega. Sprva je površinski tok potekal do Begunj, tam pa je voda ponikala in nadaljevala pot podzemsko v smeri proti Logatcu (to je bila Begunjščica, predhodnica današnje Cerkniščice). To so potrdile najdbe značilnih sedimentov, ki so bili najdeni v brezstropih jamah v Ravniku. Okrog 50 ka nazaj je reka spremenila smer in začela teči proti Cerkniškemu polju.

Starejši raziskovalci so menili, da se terase (uravnave) v porečju pojavljajo v večih nivojih, izkazalo pa se je, da se pojavljata le dva značilna nivoja. Vzdolž Cerkniščice, 10 do 40m nad rečnim dnom, se uravnave pojavljajo na večih mestih. V zgornjem delu porečja se nahajajo na 
nadmorskih višinah med 690 in 630m, v spodnjem delu, pri Begunjah, pa na nadmorskih višinah med 630 in $610 \mathrm{~m}$.

Značilni tovor današnje Cerkniščice v glavnem predstavljajo dolomitni prodniki, vmes pa so primešani koščki ooloitnih boksitov in črnih rožencev. Nahajališča teh dveh kamnin se nahajajo višje v porečju. Pri kartiranju omenjenih uravnav sem prav tako naletela na enake sedimente, zato sem predpostavljala, da je tudi ta material tja prinesla Cerkniščica.

Preden se je Begunjščica preusmerila na Cerkniško polje, je ponikala pri Begunjah in podzemsko tekla v smeri proti Logatcu. To so potrdile najdbe dolomitnih prodnikov, oolitnega boksita in črnega roženca, ki se razprostirjo na približno pol kvadratnega kilometra velikem območju južno od Begunj. Te sedimente je moč najti le do nadmorske višine $610 \mathrm{~m}$. Višje se ti sedimenti ne pojavljajo več, ampak se tam nahajajo brezstrope jame.

Da bi potrdila ali ovrgla hipotezo, da se v porečju pojavljata le dva nivoja uravnav, sem uporabila matematični model za ugotavljanje uravnoteženosti vzdolžnih rečnih profilov.

Vzdolžni profil Cerkniščice (graf 1) je skoraj uravnotežen, vendar nikjer popolnoma. Izkazalo se je, da je bil tudi rekonstruirani tok Begunjščice skoraj v celoti uravnotežen, in sicer na nekdanje ponorno območje pri Begunjah. S primerjavo višin rekonstruiranega profila v posameznih točkah in današnjo višino uravnav $\mathrm{v}$ istih točkah se je pokazalo, da uravnave vzdolž Cerkniščice niso terase, ki bi ustrezale večfaznemu vrezovanju, ampak pripadajo enotnemu nivoju. Kasneje, po pretočitvi na Cerkniško polje, se je v to uravnavo vrezala Cerkniščica. Tudi nekateri glavni pritoki Cerkniščice (graf 2, 3 in 4) še niso uravnoteženi. Zgornji deli profilov so bili uravnoteženi na Begunjščico in s pomočjo teh delov sem lahko rekonstruirala njihove nekdanje tokove. Nato sem primerjala izračunane nadmorske višine $\mathrm{v}$ točkah njihovega izliva $\mathrm{v}$ Begunjščico z izračunanimi nadmorskimi višinimami Begunjščice na tistih mestih. Izkazalo se je, da se nadmorske višine skoraj popolnoma ujemajo pri potokih Jazbine in Mahneščica, pri Mali Cerkniščici pa razlika znaša 70m. Tako odstopanje verjetno lahko razložim kot posledico mlajšega neotektonskega delovanja.

Na koncu lahko zaključim, da:

- $\quad$ sta se v porečju Cerkniščice izvršili le dve fazi vrezovanja v podlago;

- je bila Begunjščica (predhodnica Cerkniščice) skoraj popolnoma uravnotežena na ponorno območje pri Begunjah;

- obstajata le dva značilna nivoja: starejši, ki ga je izdelala Begunjščica in mlajši, ki je posledica vrezovanja Cerkniščice v starejši nivo;

- je bila preusmeritev Cerkniščice na Cerkniško polje katastrofalni dogodek;

- je nekdanje ponorno območje Begunjščice nekaj deset metrov nižje od grebena med ponornim območjem pri Begunjah in Cerkniškim poljem.

Še vedno pa ostajata odprti dve vprašanji: kako in zakaj je prišlo do preusmeritve toka, če se na grebenu med nekdanjim ponornim območjem in Cerkniškim poljem nikjer ne pojavljajo značilni sedimenti? Odgovor dajejo najdbe večih večjih brezstropih jam na tem območju. Le-te pripadajo zelo staremu jamskemu sistemu, ki se je razvil pred več kot $2 \mathrm{Ma}$, še pred premikom ob Idrijskem prelomu. Ta jamski sistem je statistično predvidel že F. Šušteršič. Zelo verjetno je, da je Begunjščica v določenem trenutku reaktivirala že obstoječi jamski sistem. Sčasoma je voda kanale vedno bolj korodirala in širila, da niso več vzdržali svoje teže stropov in stropi so se jim porušili. $S$ tem je podzemski tok postal površinski in tekom časa se je izoblikovala globoka vrezana dolina. Z nadaljnjimi raziskavami pa bo potrebno ugotoviti, zakaj se pretočitev ni izvršila že prej. 